Article

\title{
An Exploratory Study of the Learning of Transferable Skills in a Research-Oriented Intensive Course in Atmospheric Sciences
}

\author{
Taina Ruuskanen *, Hanna Vehkamäki, Laura Riuttanen and Antti Lauri \\ Institute for Atmospheric and Earth System Research/Physics, Faculty of Science, University of Helsinki, \\ P.O. Box 64, 00014 Helsinki, Finland; hanna.vehkamaki@helsinki.fi (H.V.); laura.riuttanen@helsinki.fi (L.R.); \\ antti.lauri@helsinki.fi (A.L.) \\ * Correspondence: taina.ruuskanen@helsinki.fi; Tel.: +358-503-175-409
}

Received: 9 January 2018; Accepted: 27 April 2018; Published: 1 May 2018

\begin{abstract}
Transferable skills, such as learning skills as well as oral and written communication skills, are needed by today's experts. The learning of transferable skills was studied during a multidisciplinary two-week, research-oriented intensive course in atmospheric sciences. Students were assessed on their experience of learning data analysis, writing reports and articles, oral presentation, learning and teaching, as well as project and time management skills and the importance of learning these transferable skills in the beginning and at the end of the course. The learning outcomes were constructively aligned with the course and it supported the learning of transferable skills needed by researchers working with multidisciplinary research questions. The methods of teaching were group work, data analysis of real scientific questions and real scientific data, a few expert lectures, discussions with experts and peer-support, and the course evaluation that was based on the groups' oral presentations and a written report. The groups consisted of seven to eight students and four to six assistants who were working side-by-side for the period of the course. Students considered data analysis, including the formulation of research questions, as the most important transferable skill of the course and stated that it was also what they learned the most. We conclude that the students felt that working with real scientific questions and data in multidisciplinary groups supports the learning of transferable skills. The findings suggest that the students may have learned transferable skills from peers, assistants, and teachers while working in small groups of students in different stages of their studies. The study was conducted from student feedback from one course only, but we have observed while organizing over 50 similar courses that working on real scientific questions and data in a multidisciplinary and multicultural course has been motivating for both the teachers and the students. We recommend this method to be used by research groups who are training the future generation of researchers and experts in atmospheric sciences and other fields.
\end{abstract}

Keywords: transferable skills; data-analyzing skills; multidisciplinary; intensive course

\section{Introduction}

Solving sustainability challenges requires a broad set of transferable skills, such as learning intercultural communication, and creative problem solving [1,2]. Atmospheric research is an example of a modern supradisciplinary research field that tackles today's grand challenges [3]. Obtaining sustainable solutions to climate change and air quality problems requires interdisciplinary collaboration for which new transferable skills are needed, in addition to traditional subject-specific knowledge and skills (for example, Reference [4]). 
The term transferable skills refer to a set of skills that are applicable in more than one context [5]. These skills are, for example, written and verbal communication skills, interpersonal skills, problem-solving skills, as well as information technology and self-management skills. These skills are needed in work-life; employers ask for transferable skills (for example, communication, teamwork, and presentations skills) in job advertisements [6].

Teaching and learning multidisciplinary and transferable skills are essential in atmospheric research that involves several fields of science such as chemistry, physics, meteorology, mathematics, biology, agricultural and forest sciences, technology, and geosciences, which combine observations, experimentation, and modelling. A shift from discipline-tied fundamental education towards multidisciplinarity is imperative for a successful career in climate and global change science [7].

Problem-based learning and teamwork in interdisciplinary groups have been used as teaching methods in medical, nursing, and dental schools [8,9]. Studies have shown the importance of collaboration for specialized professionals [10], as well as the importance of students' informal social activities in breaking down interdisciplinary barriers [11].

In engineering, studies on laboratory courses have shown that working hands-on with real data improves the study results [12]. In environmental education, interdisciplinary teamwork has been recognized as valuable preparation for the profession in undergraduate programs [13]. Also, problem-based learning has been successfully implemented in teaching research methods in geography [14]. The research-oriented intensive course concept studied here combines: (1) the learning of transferable skills during hands-on research work with the help of teachers and assistants and (2) the science accelerator workshop where researchers working as assistants and teachers on the course have the opportunity to explore new scientific ideas in a fertile multidisciplinary group. During the research-oriented intensive courses, students and teachers create new knowledge together and learn from peers. As an example, a master-level forest ecology student can be an expert on photosynthesis compared to a meteorology postdoctoral researcher, and the transfer of knowledge, teaching, and learning can be fostered among course participants in different stages of their studies and career. Some of the research done on research-oriented intensive courses has been published in scientific articles. As an example, ultrafine aerosol particle formation and growth in boreal forest [15] was studied in a course in 1996 and the published article has been cited 393 times so far. We will focus here on the learning aspect of the course. As far as we know, this is the first article studying the learning of transferable skills needed in atmospheric sciences on a higher-education level. Our hypothesis is that students will learn transferable skills that they need as experts while working together on real scientific questions and data with the help of more experienced peers, teachers, and assistants in a multidisciplinary and multicultural research-oriented intensive course.

\section{Methods}

While organizing more than 50 research-oriented intensive courses over the past 20 years, the Division of Atmospheric Science at the University of Helsinki has developed a practice that supports multidimensional learning outcomes in a multidisciplinary atmospheric science course [16]. Course practices, for example, scheduling and the principles of group division, as well as the assumed learning outcomes, are largely based on experience and tacit knowledge. In order to crystallize the learning outcomes for each course, it is important to analyze which transferable skills the students expect to learn, how well it is realized during these courses, and how useful the learned skills are for their development as researchers. This serves also to determine whether the learning outcomes are constructively aligned with the teaching and evaluation methods [17].

These courses follow a pedagogical approach that we have adopted during the past 20 years. On the one hand, our approach follows the experiential learning process described by Kolb [18], emphasizing the learner's personal growth and the significance of reflecting the learner's feelings and experiences. On the other hand, we follow the horizontal learning principle [19], which emphasizes learning in a heterogeneous group that includes students and teachers from different disciplines. 
In such a group, everyone takes on two roles: a learner and a teacher. This allows for the social construction and the sharing of information and cognition. We have learned that by applying the horizontal learning principle, the groups are able to address a cross-section of knowledge from different fields and blend the information to reach new levels of understanding. We have also noticed that motivation and sociability blossoms in these small groups.

\subsection{Course Settings}

In this study, we investigated the "Winter School 2017-Atmospheric Processes and Feedbacks and Atmosphere-Biosphere Interactions" intensive course (Figure 1) that was held on 6-17 March, 2017 in the Hyytiälä Forestry Field Station in southern Finland [20]. For the course, the students were asked to find answers to certain scientific questions and reformulate the scientific hypotheses by analyzing data measured at the Hyytiälä SMEAR (Station for Measuring Ecosystem-Atmosphere Relations) II station since 1996. The dataset consisted of a wide variety of meteorological, atmospheric, and ecosystem-related parameters, such as temperature, wind speed, wind direction, relative humidity, solar radiation, trace gas concentrations and fluxes, aerosol particle concentrations and fluxes, and photosynthetic activity. The course scope was 5 ECTS (European Credit Transfer and Accumulation System) and it contained pre-course assignments ( 8 academic hours, 45 min each), a 10-day intensive course in a field station ( 87 academic hours), and the writing of a course report ( 40 academic hours) after the intensive course. During the intensive course, the teaching program was from 8 am to $8 \mathrm{pm}$. with different voluntary social activities in the evenings. The 10-day intensive course contained 8 academic hours of lectures, 65 academic hours of group work, 6 academic hours of field measurement site excursions, $8 \mathrm{~h}$ of student group presentations, and 67 academic hours of social time that included meals. The groups were given freedom to organize their working schedule and some students worked during the hours allocated to social time.

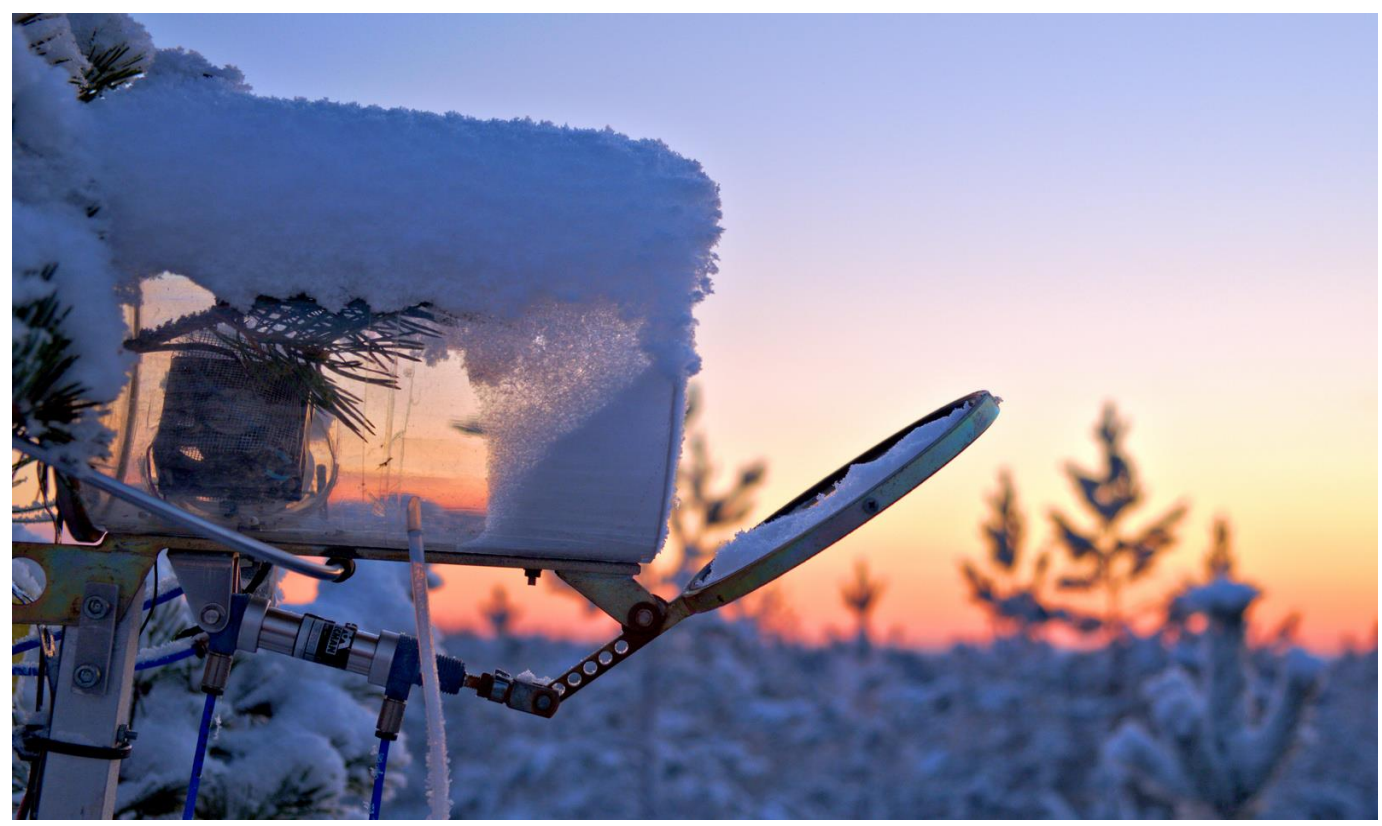

Figure 1. Students' feedback was that they learned transferable skills by working on research questions using atmospheric data obtained at the SMEAR II field station at the research-oriented intensive atmospheric sciences course "Winter School 2017 - Atmospheric Processes and Feedbacks and Atmosphere-Biosphere Interactions". Photo of Scots pine shoot measurements by Juha Aalto.

The coursework was done in four groups with seven to eight students per group. Each group had a room where they worked side by side with four to six assistants. The assistants supported the 
group in formulating research questions and their role was to make sure that the presentations were ready on time and that everyone was involved in the group work. The students' need for personal support varied greatly. While some worked independently, others had an assistant instructing them with Matlab commands while they processed and analyzed the data. Coordination of assistant tasks was mainly done among each group but was also revised during the course. The lecturers followed, on a daily base, the proceedings of the group work and some assistants were moved from one group to another to have the right kind of expertise and support in the groups that needed them.

The exceptionally high student/teacher ratio of having, on average, one assistant supporting one to three students is explained by the benefits of the course setting to the research work of the teachers. This particular course provided not only the students but also the teachers with exceptional opportunities for their own development and networking. It also benefitted their own research work by, for example, providing them with new ideas for future directions of research. However, organizing such intensive courses with a high teacher to student ratio requires both teaching resources and funding to cover the running costs of transportation to the field site as well as accommodation and meals. The work plan of the University of Helsinki teaching and research staff includes teaching responsibility ranging from teaching-intensive professors and university lecturer positions to postdoctoral and $\mathrm{PhD}$ student positions with a teaching obligation of $5 \%$ of working time. A course fee cannot be requested from the University of Helsinki degree students, but they can be requested to pay for direct course costs such accommodations and meals. Costs of the research-oriented intensive courses have been covered by the University of Helsinki education budget, which has been complemented by national, regional (Nordic), and EU-funded education and research projects. This particular research-oriented intensive course was offered for students from all around the world for a course fee of $€ 1400$ that covered the running costs of the students and their assistants. The course resources rely on research collaboration—only living costs are covered for the attending the teachers and assistants-and keeping the running costs low. A location with inexpensive accommodation and meal costs is essential for keeping the course expenses at an affordable level for both the organizers and the students.

The students used data distributed by the assistants and selected variables from the open data portal AVAA-atabase [21] (http:/ / avaa.tdata.fi/web / smart) to look for correlations and causalities based on various hypotheses. The central computational tool utilized during the course was Matlab by MathWorks. It was used to produce detailed plots of the selected data, analyze the data, and test models for the hypothesized processes. Students were also allowed to use other software, but learning support was only provided for Matlab. Student groups gave three oral presentations during the course and returned a written report after an intensive period at the research station.

We investigated the students' expectations and assessment of learning concerning the following transferable skills that were the key learning goals in the course:

1. Data analysis skills: The students' practiced formulation of research questions for data analysis. They planned and performed data processing. This included the learning of technical Matlab skills.

2. Writing reports and articles: The students performed independent and collaborative writing. They also reviewed each other's texts for the final course report, which summed up each group's findings.

3. Oral presentation skills: Student groups gave several short talks on their research plans and results to the course participants and learned how to present research methods and results to an expert audience.

4. Learning and teaching skills: For this course, the learning skills were enhanced by following how others find, process, and use new knowledge and tools. The students were also encouraged to share their findings and knowledge, especially within their group, and thus enhance their teaching skills.

5. Project and time management: The groups delivered results several times during the two-week course in the form of group talks, for which each student gave a short part of an oral presentation. 
This approach was aimed to facilitate learning to meet internal group deadlines as well as to deliver group results on schedule.

Additional learning goals of this course were to become aware of the possibilities that a comprehensive field station can provide for scientific research [20], to become aware of and broaden their personal comfort zone [22] in order to improve their personal learning skills, and to experience the challenges and benefits of interdisciplinary dialogue by being exposed to multidisciplinary group discussions for two weeks. One of the course aims was for students to gain an understanding of the underlying physico-chemico-biological processes and their interdependencies, but since the learning outcomes of the subject matter were different for each student and because it depended on their field and stage of study, we did not concentrate on learning the subject matter, focusing instead on the learning of transferable skills.

Group work had a central role on the course and the performance of each student for the course was not evaluated individually, but grading was based on the groups' written group report that was finalized about a month after the intensive course. Learning with the support of peers and the concept of cooperative learning within the zone of proximal development has already been presented by Vygotsky [23] in the context of how children learn new skills. Working in groups can increase motivation, especially for inferior group members, when the tasks are conjunctive [24]. Hennessy and Murphy [25] proposed that peers on the same level of knowledge can also facilitate collaborative learning, especially when the collaboration is planned and guided by teachers. Active learning, interaction, and discussion are highlighted also by Scott [26] as essential components of a successful intensive course. Working on a real research question can be seen as similar to learning through an inquiry method similar to the hackathon method [27], where teams work on real-life challenges and through collaboration form solutions from scratch. Working on a real research question has also been shown to facilitate collaborative learning [28], with students gaining and creating knowledge as well as simultaneously acquiring transferable skills. Learning in a work setting such as group work on real scientific questions can lead to higher motivation and lower tendency to free ride compared to standard study room settings [29]. Another advantage of collaboration is that it makes the thinking processes more explicit, supporting the development of metacognitive skills and learning [30]. Isomöttönen and Tirronen [31] have studied group work patterns in a programming course and identified free riding as a possible problem when the motivation and previous skills of students necessarily differ.

\subsection{Study Settings}

The course had 31 students, 19 assistants, and 12 lecturers. The students' level of study ranged widely: 1 student was at the bachelor's level, 6 were at the master's level, 18 were in their first year, 1 was in their second, and 4 were in their third year of $\mathrm{PhD}$ studies, and there was 1 postdoctoral researcher. They came from the fields of physics, meteorology, atmospheric science, earth science, and biology/ecology. The 31 students represented 16 nationalities (Bangladesh, Bolivia, China, Denmark, Estonia, Finland, France, Germany, Greece, India, Iran, Iraq, Italy, Kazakhstan, Norway, and Sweden) and half of them were students at the University of Helsinki. The students were divided into four groups of seven to eight students. Each group had a room where they worked side by side with four to six assistants.

The 19 assistants for the course were mainly doctoral students and postdoctoral researchers at the Division of Atmospheric Sciences at the University of Helsinki. The 12 lecturers were either professors of the Division of Atmospheric Sciences and Department of Forest Sciences at the University of Helsinki or senior researchers who were specialists in data analysis. Out of the lecturers, seven did not stay throughout the course but visited the course briefly to give their lectures and to help the students with their project work.

Process evaluations can have various levels [32], so we used feedback collected before and after teaching [33], the evaluation of learning methods, and making transferable-skill-learning results recognizable by the students. The new world Kirkpatrick model [34] splits the training evaluation 
into four levels: (1) reactions (customer satisfaction and relevance); (2) learning (knowledge, skill, attitude, and confidence); (3) behaviors (required drivers); and (4) results (community level outcomes). The student feedback that was used in the study of the course was on the first two levels: customer satisfaction, relevant learning aims, and students' personal evaluation of their learning of transferable skill during the course. Doctoral training develops transferable skills needed for both research- and nonresearch-intensive careers, as was found in a self-assessment survey of science PhDs $(n=8099)$ [35]. When a research-intensive university's program of about 80 courses for transferable-skill development was evaluated, Walsh et al. [36] observed that when the skills are not considered "extra" but are a part of core activities, students report even more positive impact from learning them as well as a more positive attitude towards the skills [36]. Especially, a residential 3-day course called the "Research Skills Development Course" for first-year students had a positive impact on students' perception of their skill level [36]. To our knowledge, learning of transferable skills on short research-oriented courses with different students at different stages of their studies has not been studied earlier. However, there exist studies on group supervision of $\mathrm{PhD}$ students (e.g., [36-39]) that can be considered to have similarities in having a group of students at different stages of their program learning with and from each other and their supervisors. Some doctoral program studies even have aspects of peer and collaborative learning of transferable skills among students at different levels of their studies as well as members staff [40], and also studies related to general learning patterns on intensive courses [26,41].

Another learning aspect of the study was programming skills, which are a programming-language specific, technical part of the course's data-analysis skills learning aim. Based on our experience and students' application letters to the course, many students expected primarily to learn to use Matlab in this course. Some teachers of the course have criticized this and suggested a separate Matlab course or other means to ensure that the students have a sufficient command of Matlab before they entered this course. Thus, specific attention in this study was paid to the role of Matlab skills in the course: Did students expect to learn to use Matlab? How did students assess the role of learning Matlab skills in their expectations before and evaluations after the course? Were Matlab skills limiting the learning of different transferable skills? Matlab is a justified choice of toolbox for this course, as a comparison with different software packages shows that Matlab excels in demonstrating multivariable iterative processes and has been verified to promote a deeper understanding of process-modelling techniques [42]. The course combines aspects of data science and computational modelling in a project-oriented manner, as suggested by Giabbanelli and Mago [43], to be the way forward in teaching computational science. Thus, this kind of course could also serve for primarily learning computational methods.

Student feedback was collected to improve the practices of this annual course, as well as other intensive courses based on a similar concept. The answerers were asked to give or decline permission to use the results for research purposes after informing them that parts of the text (the last question in the questionnaires, Appendix A) would be published anonymously. In total, 29 students answered the pre-course survey, and in this report, we have included data on the 28 of them who gave us permission to use their answers. Similarly, for the after-course survey, out of 20 students who answered the survey, we consider only the 19 who gave us permission to use the data. The gender distribution was fairly equal ( 15 males versus 13 females in the pre-course survey, 9 males versus 10 females in after-course survey), and so was the distribution of students from the University of Helsinki (13 in the pre-course survey, 10 in the after-course survey) and from other universities (15 in the pre-course survey, 9 in the after-course survey). More than two-thirds of the student answers in the after-course survey contained detailed answers to the open questions. The timing of the after-course survey was somewhat problematic, since students had not started writing the course reports, and thus the answers to questions concerning transferable skills "Writing reports and articles (independent writing, collective writing, reviewing others' texts)" were not fully representative.

Our hypothesis was that students learn transferable skills that they need as experts while working together on real scientific questions and data with the help of more experienced peers, teachers, 
and assistants in a multidisciplinary and multicultural research-oriented intensive course. We aimed to uncover whether the stages of studies, fields of study, and previous experience in using data analysis software, or other background information systematically correlated with the learning expectations and perceived learning. We also assessed how well the learning expectations were met and which activities were considered most fruitful for learning the various transferable skills. Special attention was paid to the role of Matlab in the course and group work dynamics.

\subsection{Research Methods}

The teaching process evaluation in the development of projects can have various levels [32] and thus we focused on the systematic collection of feedback, development of learning methods, as well as making transferable skill learning visible. Since the performance of each student for the course was not evaluated individually but was based on the written group report that was finalized about a month after the intensive course, we were unable to compare the students' experience of learning to actual performance. The scope of this study does not allow for the testing of students' skills separately. Rather, in this study, we relied on the students' subjective assessment of their learning process. In order to evaluate learning and not just the experience of it, a separate study should be conducted where the students' starting levels would be compared to their development during the course and the application of transferrable skills in the work environment. However, since the course participants would be students, it could be problematic to distinguish the transfer of skills from other learning environments. Thus, personal evaluations done at the beginning and end of the course could give insight and indications of the actual learning.

We designed two surveys: the pre-course survey on the first morning of the course and an after-course survey on the last day of the course. In designing these surveys, we also used the information the students provided in their course applications regarding their previous knowledge and studies as well as their motivation to attend the course and their expectations of the course. Background information questions were repeated at the beginning of each survey and we did not link the answers of the pre- and after-course surveys together. As only one course was studied, the statistical analysis will necessarily be poor as it represents the answers of fewer than 30 people from various backgrounds. The evaluations of the students who took part in the study should be considered as examples and other students, as well as students at research-oriented intensive courses organized at different years, may have different learning experiences of the teaching method. However, combining the numerical answers with open-ended answers from students of the Winter School 2017 gave us insight into the learning experience of the course.

\section{Results and Discussion}

\subsection{Expectations Versus Assessed Learning, Learning through Different Activities}

The students experienced progress in learning all the mentioned 5 transferable skills during the 10 days of the research-oriented intensive course. The students considered data analysis as the most important skill among these. Overall, the learning expectations were slightly higher than the assessment of learning during the course (Table 1). However, the personal importance of all these skills had increased slightly during the course, probably indicating an acute awareness of the usefulness of these skills. Since recommendations of an evidence-based evaluation is for graduate training programs to offer opportunities to (a) improve awareness and (b) to acquire transferable skill [35], students may become aware of the skills they possess or need only later in their career. Sinche et al. [35] studied the usefulness of 15 transferable skills, including "ability to analyse data", "oral communication skills", and "written communication skills". Most of the skills were transferable for both research- or nonresearch-oriented careers, with the exception that creativity/innovative thinking, career planning and awareness skills, and ability to work with people outside the organization favored research careers, while time management, ability to learn quickly, and ability to manage a project favored nonresearch 
careers [35]. The expectations were highest concerning data-analysis skills, and the students also felt that they learned data analysis more than the other transferable skills. The learning expectations and assessments differed most for the writing skills, which can be at least partly explained by the fact that the course report had not been written during the time the after-course survey was conducted. Some of the difference between the results of the pre- and after-course surveys may be explained by the fact that the 19 students who answered the after-course survey form a possibly biased subset of the 28 students who answered the pre-course survey. Overall, the number of students was too small for a sound statistical analysis. The only statistically significant differences were the personal importance and learning in data analysis and the learning project and time management. Transferable-skill gaps between what is developed during doctoral training and what is required for success on the job after graduation were found for "time management", "ability to work on a team", "ability to work with people outside the organization", and "ability to manage others" [35], which indicates that project and time management should be particularly emphasized.

Table 1. The average results (standard deviation in parentheses) of the pre-course and after-course surveys on learning transferable skills $(0=$ not at all, $4=$ very much). The differences that were statistically significant in the two-tailed $t$-test at $5 \%$ significance level are bolded.

\begin{tabular}{ccccccc}
\hline & \multicolumn{3}{c}{ Personal Importance } & \multicolumn{3}{c}{ Learning } \\
\cline { 2 - 7 } & $\begin{array}{c}\text { Before } \\
\text { Course }\end{array}$ & $\begin{array}{c}\text { After } \\
\text { Course }\end{array}$ & Difference & $\begin{array}{c}\text { Expectation } \\
\text { of Learning }\end{array}$ & $\begin{array}{c}\text { Assessed } \\
\text { Learning }\end{array}$ & Difference \\
\hline Data analysis & $3.4(0.8)$ & $3.6(0.5)$ & +0.2 & $3.7(0.5)$ & $3.2(0.8)$ & $-\mathbf{0 . 5}$ \\
Writing reports and articles & $3.3(1.1)$ & $3.5(0.8)$ & +0.2 & $3.1(0.8)$ & $2.2(1.0)$ & $-\mathbf{0 . 9}$ \\
Oral presentation & $3.0(1.1)$ & $3.4(0.8)$ & +0.4 & $2.8(1.1)$ & $2.5(1.1)$ & -0.3 \\
Learning and teaching & $3.1(0.9)$ & $3.3(0.7)$ & +0.2 & $2.5(1.0)$ & $2.0(1.1)$ & -0.5 \\
Project and time management & $2.9(1.1)$ & $3.2(0.8)$ & +0.3 & $3.0(0.8)$ & $2.3(1.2)$ & $-\mathbf{0 . 7}$ \\
\hline
\end{tabular}

The students felt that they learned most during the group work, which was expected as the course was designed so that they spent most of their study time working in groups (Table 2). The data-analysis (including Matlab) and oral-presentation skills were learned mostly via group work and working with real scientific questions and data based on the student feedback. Students also experienced that their learning and teaching skills, including multidisciplinary collaboration and sharing of knowledge within the group, improved during the group work and through studying real scientific questions. Also, the social time that was designed to facilitate informal discussions across the working groups and with teachers at the course was considered valuable for learning. The value of informal communication and relationships for intensive courses was also found by Scott [26]. The preparation of the final report was considered to support the report-writing skills most strongly. However, most of the report preparation was done after the after-course questionnaire, and thus this part of the learning should be considered more as an expectation.

Table 2. The learning of transferable skills through different activities, the average of the results, and the standard deviation in parentheses, based on the after-course questionnaire $(0=$ not at all, $5=$ very much. Note the different scale compared to Table 1). Values larger than 3 are bolded.

\begin{tabular}{|c|c|c|c|c|c|}
\hline Activity & $\begin{array}{c}\text { Data } \\
\text { Analysis }\end{array}$ & $\begin{array}{l}\text { Writing } \\
\text { Reports }\end{array}$ & $\begin{array}{c}\text { Oral } \\
\text { Presentation }\end{array}$ & $\begin{array}{c}\text { Learning } \\
\text { and Teaching }\end{array}$ & $\begin{array}{c}\text { Time } \\
\text { Management }\end{array}$ \\
\hline Lectures & $1.3(1.4)$ & $2.5(1.4)$ & $2.0(1.5)$ & $2.1(1.5)$ & $1.4(1.5)$ \\
\hline Discussions with Experts & $2.1(1.7)$ & $1.9(1.6)$ & $2.2(1.7)$ & $2.4(2.1)$ & $1.3(1.3)$ \\
\hline Real Scientific Questions and Data & $3.9(1.5)$ & $2.8(1.7)$ & $2.6(1.6)$ & $3.1(1.7)$ & $1.8(1.5)$ \\
\hline Preparation of the Final Report & $1.8(1.5)$ & $4.1(1.4)$ & $1.8(1.7)$ & $1.9(1.7)$ & $2.4(1.6)$ \\
\hline
\end{tabular}


The open answers to "What did you learn at the course" reflected the numerical evaluation of the learning of transferable skills:

- How to do data analysis. How to solve scientific problems. How to manage group work.

- I learned how to write some coding, how to focus on the same topic with people with very different knowledge, what to look at when trying to comprehend natural phenomena.

- Some important data analysis skills and finding information. Collaborative learning and working as a group.

Most of the comments were positive, but some students would have wished for clearer instructions. For example, one student wrote:

- The oral reports, I think, provided good speaking experience, but I didn't feel like they were formal or organized enough to really give me any new skills. The only thing I didn't learn anything about was writing the report since that was just thrown at us at the last minute. I don't really understand yet how that is supposed to work.

The strength of the research-oriented course is that it can foster learning with and from peers and co-workers (who can be other students), but more widely fellow academics at different stages of their research career. Developing the identity of a degree student to one learning "alongside academics and visiting scholars" is an important step in the process of "becoming a peer through participation in a community of research practice" [38]. However, the feedback suggests that the collaborative and peer learning during the group work could be strengthened with formal instructions for oral presentations and repot writing. Working side-by-side in the research-oriented field course can support both student and teacher development, and participants can show each other how the work is done rather than just focusing on the end product and results. Also, seminars can be used as "collaborative knowledge sharing environments that support students (and sometimes staff) in their research work" [40]. Wisker et al. [40] found that discussion seminars on not just results but also the process of research create "group and collaborative knowledge sharing environments to support students (and sometimes staff) in their research work". Peer learning is reciprocal, and while it is obvious that students can learn and share knowledge with each other, teachers can also learn from students when "being challenged, becoming aware of new literature and resources, joint investigation and through exposure to new data" [38] during the course.

\subsection{Effects of the Stage of Study, the Study Field, and the Home University}

The stage of the students' study did not appear to influence the learning experience of the course. Students' appreciation of collaborative learning and participant diversity was present in the student feedback. One student wrote in the course feedback: "It was really good having people from so many different backgrounds and countries". We did not find any significant differences in the answers of the students from other universities compared with the ones studying at the University of Helsinki. The feedback showed that the field of study did not have an effect on the experience of learning transferable skills. The correlation of experience of learning data analysis versus the students' study field is shown as an example (Figure 2). However, in the open-ended feedback, some students commented that it was difficult to "come up with scientific questions" or that it led to "incomprehension" if the focus of the group work was far away from the core field of the student. 


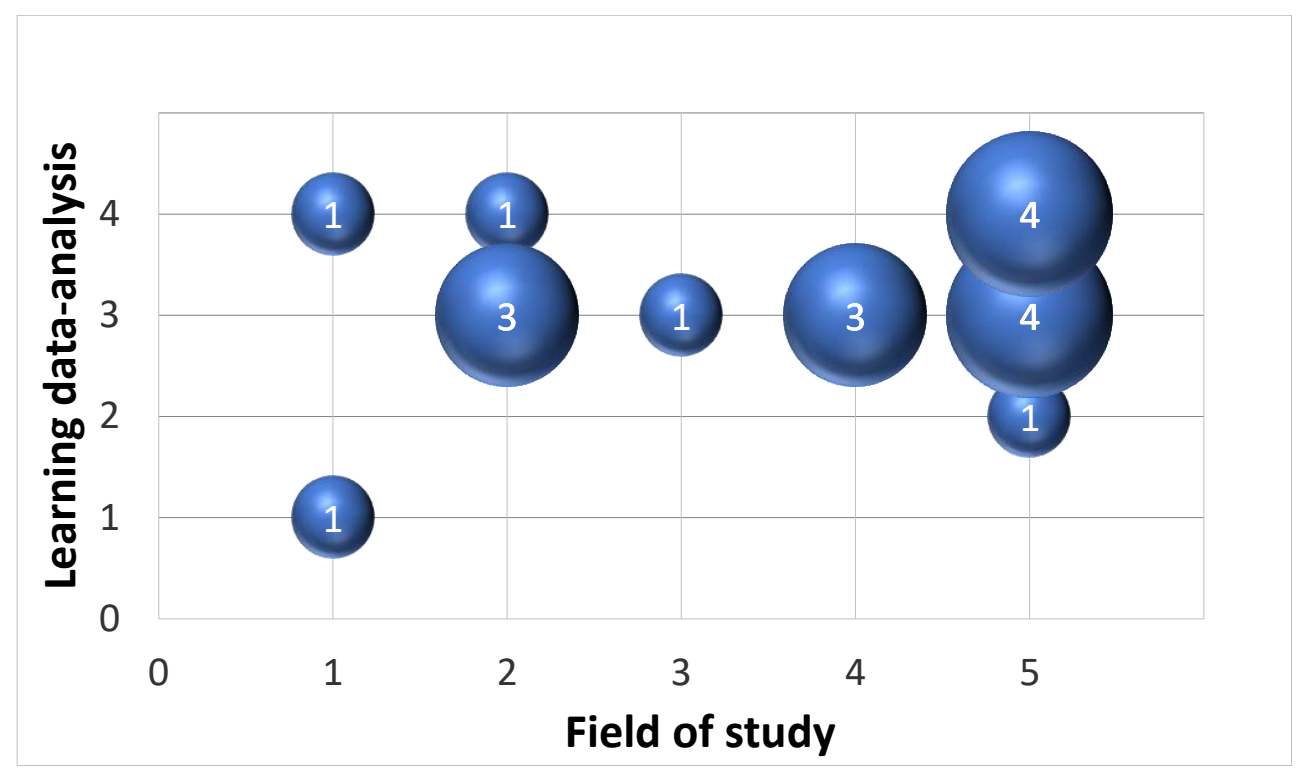

Figure 2. Students' answers on their learning of data-analysis skills for the course $(0=$ not at all; $1=$ a little; 2 = somewhat; 3 = quite a lot; $4=$ very much) as a function of the field of study ( 1 = Physics; $2=$ Forestry; $3=$ Biology; $4=$ Meteorology; $5=$ Atmospheric science). The number of students' answers in that bin is written on the circle.

\subsection{Expectation and Experiences Concerning Matlab and the Effect of Previous Matlab Experience}

Matlab or other programming experience ranged from starters to experienced users. Two students did not have Matlab experience prior to the course, but they were accustomed to another data-analysis software. None of the students considered themselves as "experts" in Matlab or any other programming software.

Irrespective of their experience in using Matlab, students expected to learn Matlab skills during the course (Table 3). Indeed, learning computational skills during interdisciplinary group work on real problems is a widely used teaching method where "problem-solving is not an academic exercise with a predetermined set of answers but rather a complex engagement" [29]. None of the students expected to be able to concentrate on the subject matter without learning to use Matlab. These expectations were fairly well met (Table 4), although three students felt they concentrated on the subject matter without learning Matlab. One of these students had no previous Matlab experience and the other two answered that they used Matlab regularly for noncomplex tasks. Thus, there is no clear correlation between previous Matlab experience and students who fall in the category of concentrating on the scientific questions without Matlab skills. In the open-ended feedback under the question "What did you learn in the course?" many students commented that they mainly learned Matlab skills. For example, students wrote: "Most of what I learned in the course was Matlab coding skills", "My skills in Matlab became better", or "I became familiar with Matlab". One student mentioned that "I improved my Matlab skills a bit, but not as much as I would have wanted" and another student who used Matlab code without having enough information or support to get to the bottom of it stated that "I was handed Matlab codes that I had to adapt, but I still do not understand what exactly they do". Students expected to learn to both modify Matlab scripts and to write code from scratch, and to a lesser extent, to find and use existing scripts. Previous Matlab experience did not appear to have a significant effect on the students' experience on learning data analysis since we did not observe a correlation between them in the student feedback (correlation coefficient -0.22), as indicated by Figure 3. 
Table 3. Student expectations concerning Matlab at the start of the course.

\begin{tabular}{cr}
\hline Frequency & Expectations \\
\hline 12 & I expect to learn Matlab and have no or little previous experience. \\
14 & I expect to improve my already good command of Matlab. \\
0 & I expect to be able to concentrate on the scientific questions without Matlab skills. \\
2 & I do not have any expectation regarding Matlab skills. \\
\hline
\end{tabular}

Table 4. The student assessment of the role of Matlab during the course.

\begin{tabular}{cc}
\hline Frequency & Assessment \\
\hline 8 & I learned Matlab with no or little previous experience \\
8 & I improved my already good command of Matlab \\
3 & I concentrated on the scientific questions without Matlab skills \\
\hline
\end{tabular}

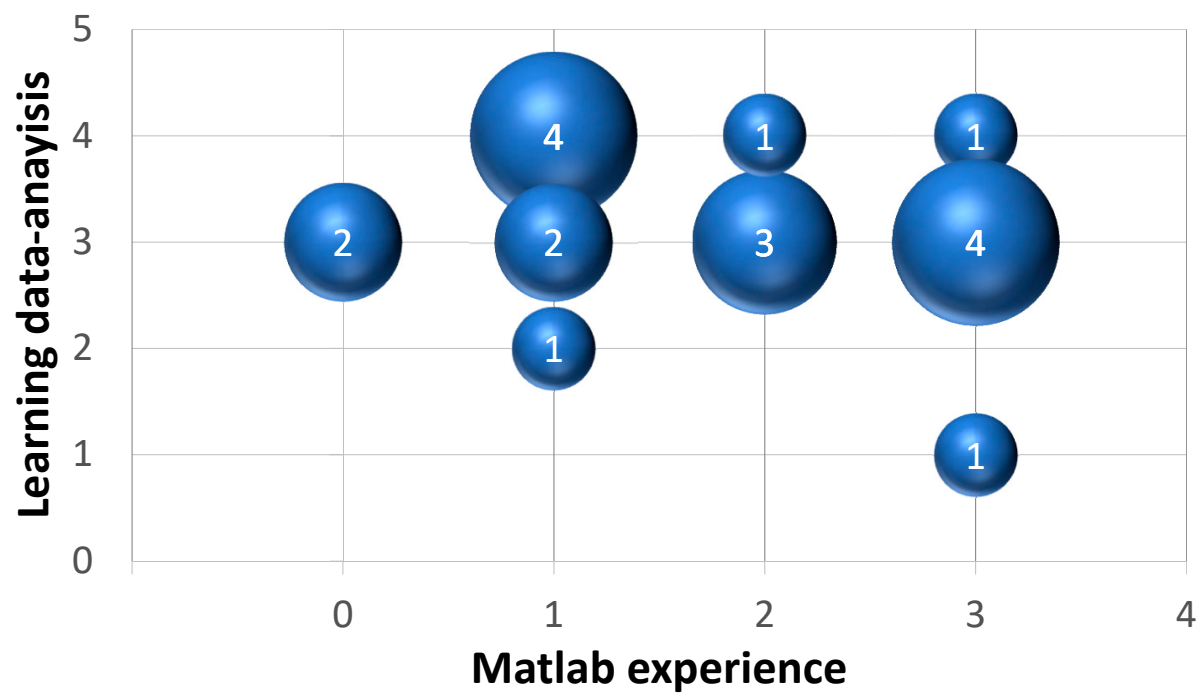

Figure 3. Students' answers on their assessed learning of data-analysis skills on the course $(0=$ not at all; $1=$ a little; 2 = somewhat; 3 = quite a lot; $4=$ very much $)$ versus Matlab experience $(0=$ no experience; $1=\mathrm{I}$ have a little experience; 2 = I use frequently for simple tasks; 3 = I have a lot of experience and am fairly comfortable with it; $4=\mathrm{I}$ am an expert). The number of students' answers in that bin in the after-course questionnaire is written on the circle.

In general, working with real scientific questions and data was considered important for learning. As an example, one student expressed that "Working with the data was also really helpful ... To get more used to the process of research and analysis in general". Doing a research project that requires both modelling and data-science skills suggests that an approach which customizes the learning experience based on students' interests is effective [43]. Giabbanelli et al. [43] recommend a class size between 10 and 12 students, equally divided as undergraduates and graduate students, and to only use datasets that were previously used for publications to ensure some standards in the data. Students with little experience in Matlab considered it slightly more important to learn than those with more Matlab experience (Figure 4; correlation coefficient -0.44). This could reflect that students with a lot of Matlab experience had already been working in real research environments more often than those with few computational data-analysis skills, and thus, this aspect of the course did not have an added novelty value for some of them. However, it is notable that the students with the most Matlab experience had the most variance in their answers. 


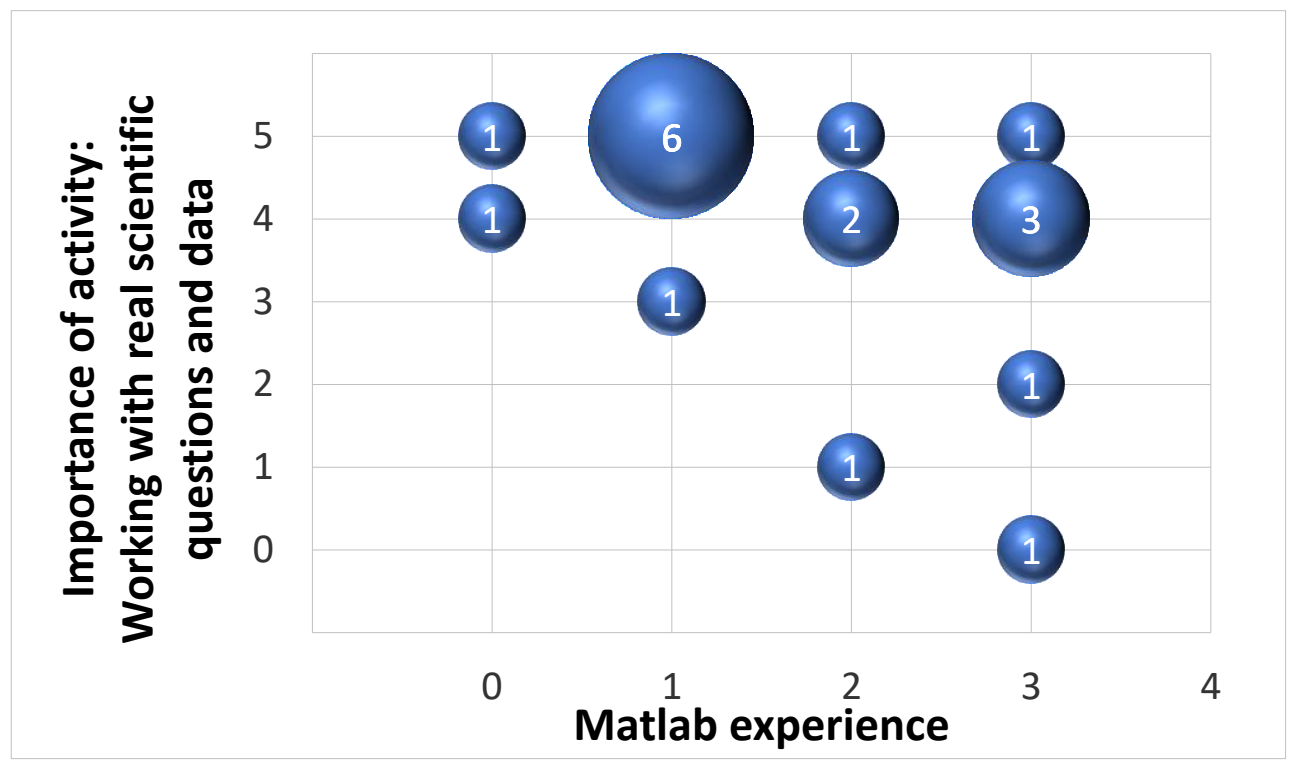

Figure 4. Students' rankings on how important working on real research questions and scientific data was for their learning on the course $(5=$ most important, 4 , second most important $\ldots 0=$ did not play any role) as a function of students' Matlab experience ( $0=$ no experience; $1=$ I have a little experience; 2 = I use frequently for simple tasks; 3 = I have a lot of experience and am fairly comfortable with it; $4=\mathrm{I}$ am an expert). The number of students' answers in that bin in the after-course questionnaire is written on the circle.

\subsection{Group Work Patterns}

The students were divided into four research/work groups which were mixed based on the students' Matlab skills, nationality, and field of study with the aim of peer support and horizontal learning. Since the optimal group size for collaborative learning in doctoral education group supervision is around six students [39], the groups in the research-oriented intensive course had six to seven students with four to five assistants working side by side with them. Collaborative learning requires enough members to produce a creative learning atmosphere, but a too-large group becomes unfriendly and competitive rather than collaborative [39]. We used the questions of Isomöttönen and Tirronen [31] to study the group work patterns (Table 5). Almost half of the students felt that they worked rather individually in the groups and this was also evident in the open-ended feedback: four students said they were happy with the group work, while another four said that the group work was frustrating due to individualism, misunderstandings, and varying preliminary knowledge. The students stated the positive sides of the group work, for example, "Group work worked well", "I think the group work was an excellent way to learn", and "I think it was all these group interactions that really ensured that I learned as much as I did from this course". Some liked the group work but expected more, as stated in the comment "I really liked working in a group, meeting some new people and learning new things, I hoped, however, that the group work topics were more carefully determined", or had a critical experience of the group work, stating that "It felt more like individual work in one room. People expressed their own desires for what they wanted to do ... " or "there should be less division inside the same group". Also, Fenge [39] observed similarly both positive "fertile and safe environment in which to test new ideas" and negative experiences where students express "feeling of vulnerability if you think that others are ahead of you" of group learning in a small exploratory study. It may have been that other groups started working together and others at the course would have required more time to do so. Doctoral supervision groups have more time to build a safe learning environment as described by a student "it took a little while to become a cohesive group, but it now feels this is a very secure, trustworthy group" [39]. Hurrying to perform their preferred task without group consensus or division of labor was named as 
one of the reasons for ineffective group work. Students did not assume/observe strong leadership in the groups and the leadership did not strongly correlate with previous Matlab experience (correlation coefficient 0.40 ), as seen in Figure 5. This indicates that although the students' experience and phase of their studies varied, the most experienced students did not automatically take group leader positions, but the group members worked equally. This demonstrates that the group assistants succeeded in their task of steering the work in groups and dividing the tasks between the students.

Table 5. The students' assessment of the group work patterns.

\begin{tabular}{cccc}
\hline Statement & $\begin{array}{c}\text { Did Not } \\
\text { Observe }\end{array}$ & $\begin{array}{c}\text { Observed to } \\
\text { Some Degree }\end{array}$ & $\begin{array}{c}\text { Describes My } \\
\text { Role Well }\end{array}$ \\
\hline $\begin{array}{c}\text { You worked independently, while the group provided a } \\
\text { support safety net }\end{array}$ & 1 & 9 & 4 \\
\hline $\begin{array}{c}\text { You took care of your own learning, and both learned } \\
\text { from and taught others }\end{array}$ & 1 & 14 & 0 \\
\hline $\begin{array}{c}\text { You took a team leader role and managed practical } \\
\text { things such as submissions and distribution of work }\end{array}$ & 13 & 3 & 2 \\
\hline $\begin{array}{c}\text { You hardly participated and took advantage of your } \\
\text { peers' answers }\end{array}$ & 14 & 8 & 1 \\
\hline $\begin{array}{c}\text { You tried but found it persistently difficult and you felt } \\
\text { that you could not follow }\end{array}$ & 10 & 6 & 0 \\
\hline $\begin{array}{c}\text { You tried (perhaps unconsciously) to hurry on to } \\
\text { particular exercises so that you could do the ones you } \\
\text { preferred before the others in the group got to }\end{array}$ & 13 & 6 & 0 \\
\hline $\begin{array}{c}\text { Because of your previous knowledge, you received a } \\
\text { dominant role in the group }\end{array}$ & 13 & 6 & \\
\hline
\end{tabular}

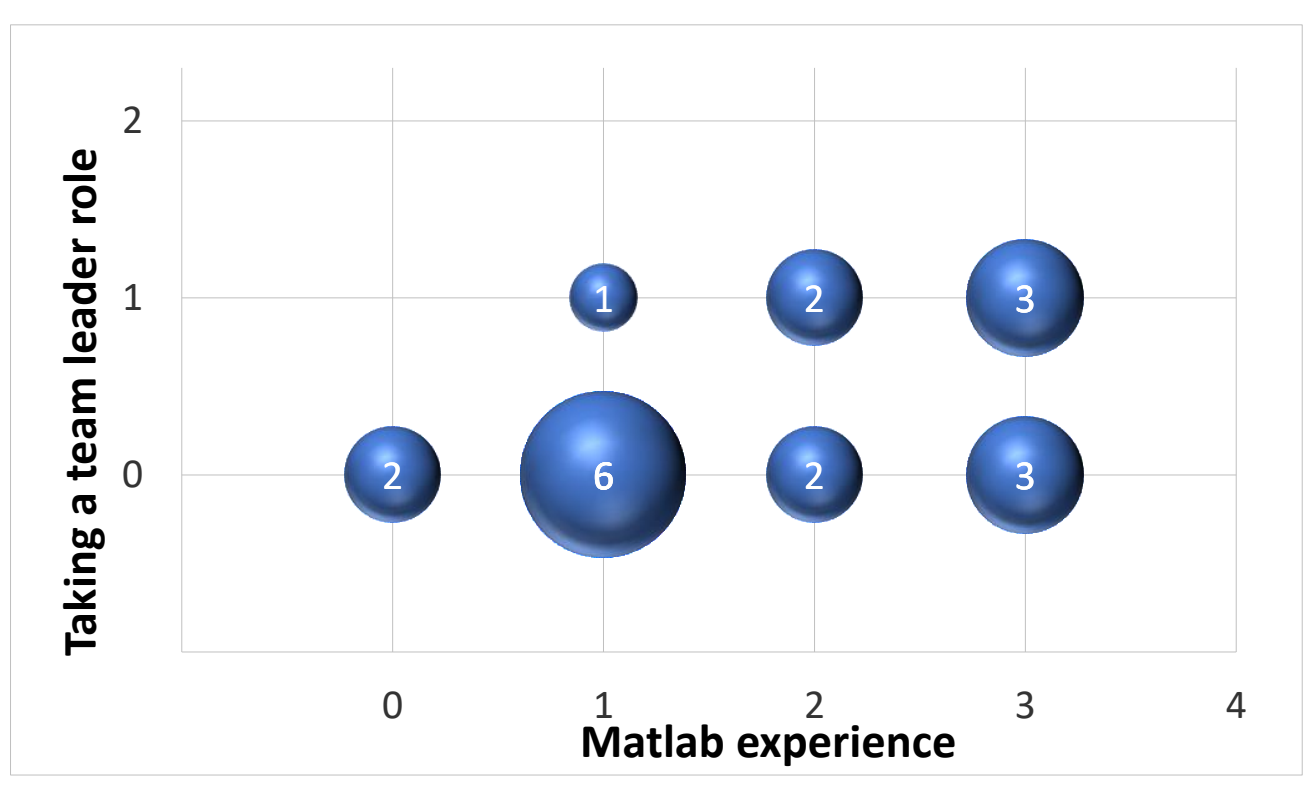

Figure 5. Students' own experience on assuming a team leader position in managing practical things such as submissions and distribution of work ( $0=$ did not observe; $1=$ observed to some degree; 2 = this describes my role well $)$ versus Matlab experience $(0=$ no experience; $1=$ I have a little experience; 2 = I use frequently for simple tasks; 3 = I have a lot of experience and am fairly comfortable with it; $4=\mathrm{I}$ am an expert). The number of students' answers in that bin in the after-course questionnaire is written on the circle. 


\subsection{Overall Assessment of the Course}

The course schedule was a compromise of finding plenty of time for the group work, having enough time for the informal and reviving social free time, and matching the schedules of those lecturers who attended only part of the intensive course. Most of the students enjoyed the course (Figure 6). Isolation from a research group, indifference, lack of support and constructive feedback from the scholarly community, and supervision were the main reasons of disengagement for doctoral students [44] and pitfalls that should be avoided at the research-oriented intensive course. The only students who disagreed with the statement "I enjoyed the course" were experienced in Matlab, indicating that the lack of previous Matlab skills was not felt as a problem, but hinting that those who were skilled in Matlab ended up doing more routine work and/or waiting for others to catch up. The correlation coefficient between Matlab experience and enjoying the course was -0.18 . In the open-ended feedback, one student reported that the assistants' time was spent on teaching Matlab to the beginners, and thus they had no time to discuss scientific issues. Figure 7 shows that the students mostly considered the workload of the course to be high. Some students specifically stated that they liked the work to free time balance: "The structure of the days and the balance between working and social time was especially good". For some other students, the workload was too high: "If the daily schedule is from 8 am to $8 \mathrm{pm}$, I get exhausted and [it] makes my produced work worse". Only two students with good command of Matlab felt that the workload could be higher. There is also some indication of free riding (Table 5), which is supported by the open-ended feedback. Some students said their background made it difficult to participate effectively in the group work. Several students commented that it would have been better if the lectures would have been concentrated at the beginning of the course. One student, for example, wrote "... suggestions I would have for improvement ... It would have been far more helpful to get the background information at the beginning" and "It would have helped a lot if ... The lecture was during the first few days".

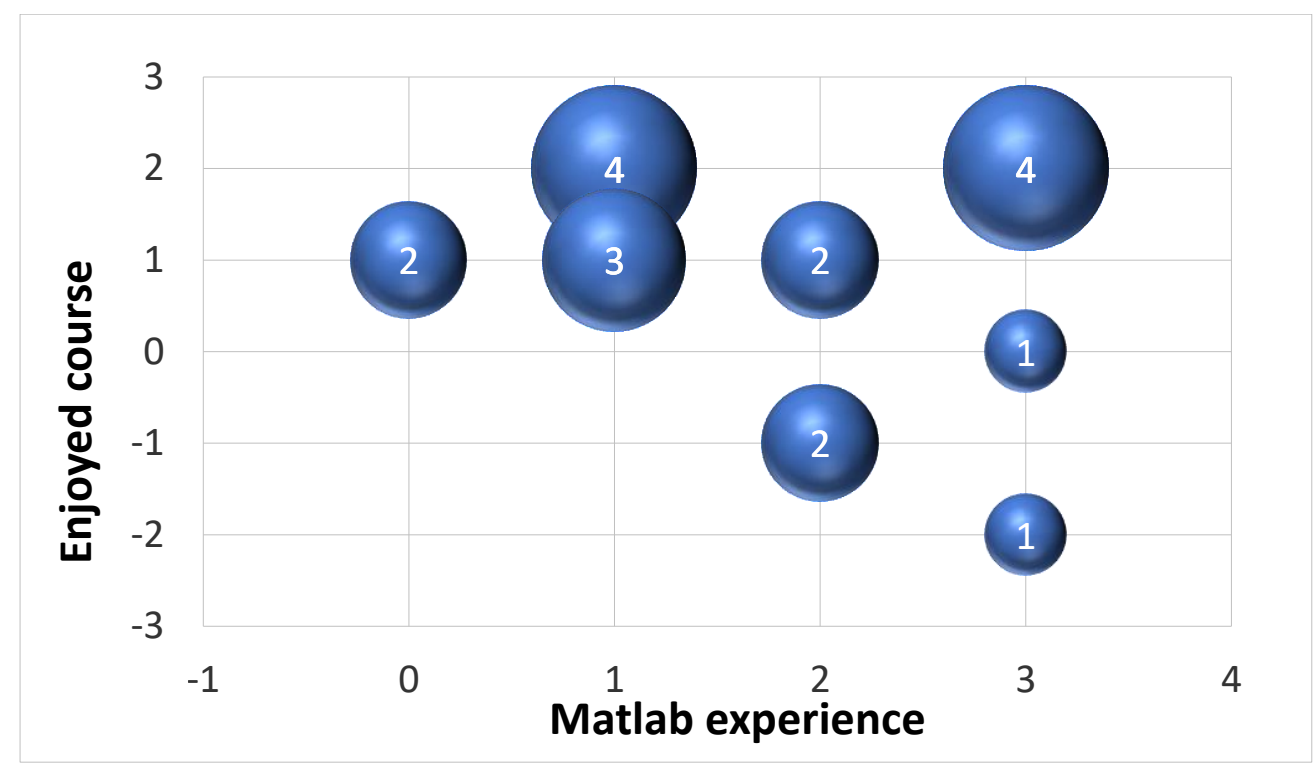

Figure 6. Students' agreement with the statement 'I enjoyed the course' $(-2=$ fully disagree $\ldots$. +2 f fully agree) versus Matlab experience reported on a scale of Matlab experience $(0=$ no experience; 1 = I have a little experience; 2 = I use frequently for simple tasks; 3 = I have a lot of experience and am fairly comfortable with it; $4=\mathrm{I}$ am an expert). The number of students' answers in that bin in the after-course questionnaire is written on the circle. 


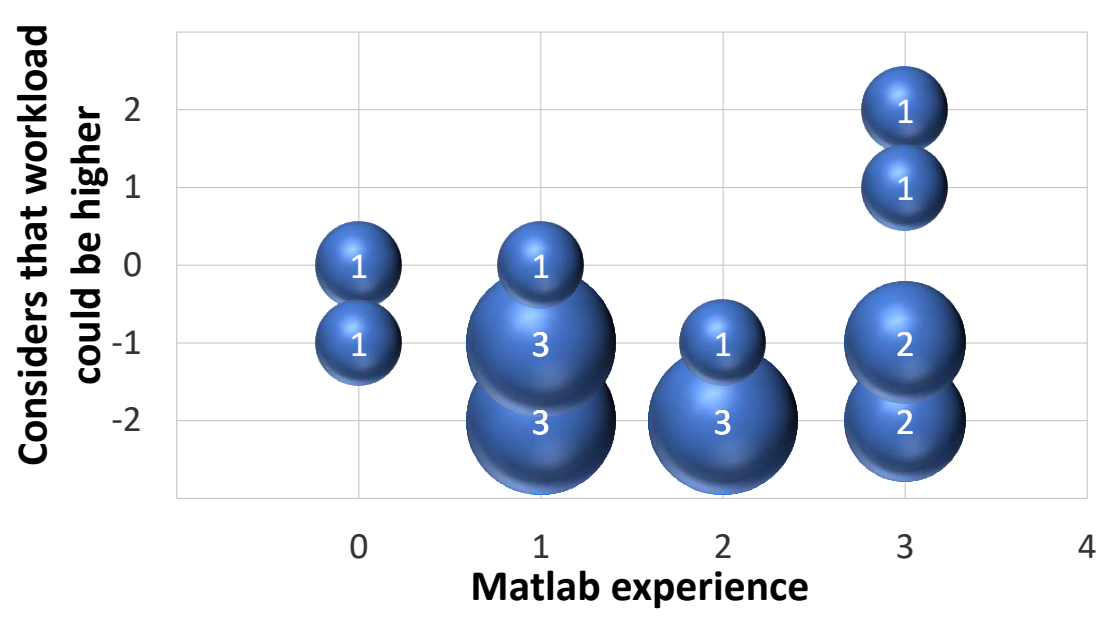

Figure 7. Students' agreement with the statement 'The workload could be higher' $(-2=$ fully disagree $\ldots+2$ = fully agree $)$ versus Matlab experience $(0=$ no experience; $1=\mathrm{I}$ have a little experience; 2 = I use frequently for simple tasks; 3 = I have a lot of experience and am fairly comfortable with it; $4=\mathrm{I}$ am an expert). The number of students' answers in that bin in the after-course questionnaire is written on the circle.

\section{Conclusions}

Conducting modern atmospheric science research requires transferable skills and the ability to work and collaborate in multidisciplinary research groups. The Division of Atmospheric Sciences at the University of Helsinki has over 20 years of experience in organizing research-oriented intensive courses that bring together different fields of science and students in different stages of study. We carried out a set of two surveys to find out about the university students' experience of learning transferable skills during a research-oriented intensive 10-day course held in March 2017.

The learning outcomes of the courses were constructively aligned with the methods of teaching that were group work, data analysis of real scientific questions and real scientific data, a few expert lectures, discussions with experts and peer support, and the course evaluation that was based on the groups' oral presentations and a written report. According to the survey conducted at the end of the course, the students enjoyed the setting provided by a multidisciplinary intensive course and felt that they had learned transferable skills during the course. Out of the named transferable skills, data-analysis skills were considered the most important both before and after the course. The student expectations in learning data-analysis skills during the course were the highest and they also felt that it was the skillset they learned the most. However, the students found other transferable skills-writing reports and articles, oral presentation skills, learning and teaching skills, and project and time management skills-rather important as well, but the assessed learning of these other skills was not as significant.

Mixing student groups from different fields and stages from undergraduate to experienced $\mathrm{PhD}$ students and postdoctoral researchers worked well. The learning of transferable skills during the course was experienced by students from all fields of science and all stages of study. In terms of learning, in general, the students appreciated or did not see it as a problem that they were mixed in multidisciplinary groups with BSc, MSc, and PhD students in the same group. However, some students reported that they felt that their background made it difficult to participate effectively in the group work. Whether the feeling of lack of contribution was due to gaps in the students' knowledge of the substance or the level of transferable skills could not be deduced from the survey data. Furthermore, one student felt that the assistants' time was taken up in teaching Matlab skills and they did not have enough time to focus on the subject matter and scientific questions. The students' lack of previous Matlab skills was not considered a problem for learning, and only students experienced in 
Matlab did not enjoy the course as much as the others. The students' previous experience in using data-analysis software or other background information did not appear to correlate clearly with the learning expectations or the experience of learning transferable skills.

The study findings suggest that the students may have learned transferable skills from peers and teachers while working in small groups on real scientific questions and data in a multidisciplinary and multicultural course. The learning of transferable skills took place with the help of more experienced peers, teachers, and assistants by working on research questions in groups that were motivating for both the teachers and the students. We recommend organizing research-oriented education where multidisciplinary student groups tackle real scientific questions using real research data. In our experience, intensive courses where groups of seven to eight students work with four to six assistants support the learning of transferable skills needed by researchers working with multidisciplinary research questions. This article described for the first time a course concept that is a research-oriented intensive course where future experts learn transferable skills in a multicultural and multidisciplinary environment with participants from different levels of university study. Transferrable skills developed during degree training are needed in research and other careers [35]. We recommend this method to be used by research groups in atmospheric sciences and other fields who are training the future generation of researchers and experts.

In the future, we will investigate what has been the scientific impact of the research-oriented intensive course for the research articles that have been fostered during them. We also plan to conduct an additional follow-up survey to assess to what extent the skills learned have become part of the students' active skillsets. The plan is also to continue using exactly the same survey over several years to improve the representability of the results.

Author Contributions: T.R. and H.V. designed and collected the student feedback, analysed the data, and wrote the results of the paper; A.L. wrote the pedagogical framework and aims of the course; all authors conceived the experiment, contributed to the analysis of the results, to the writing of the introduction and conclusions and the finalizing of the paper.

Acknowledgments: Markku Kulmala and Pertti 'Pepe' Hari are fully acknowledged for their pioneer work in establishing the research-oriented intensive course concept. The Academy of Finland (project no. 307331) and the Doctoral Programme in Atmospheric Sciences (ATM-DP, University of Helsinki, Helsinki, Finland) are acknowledged for support in organizing the course.

Conflicts of Interest: The authors declare no conflict of interest.

\section{Appendix A}

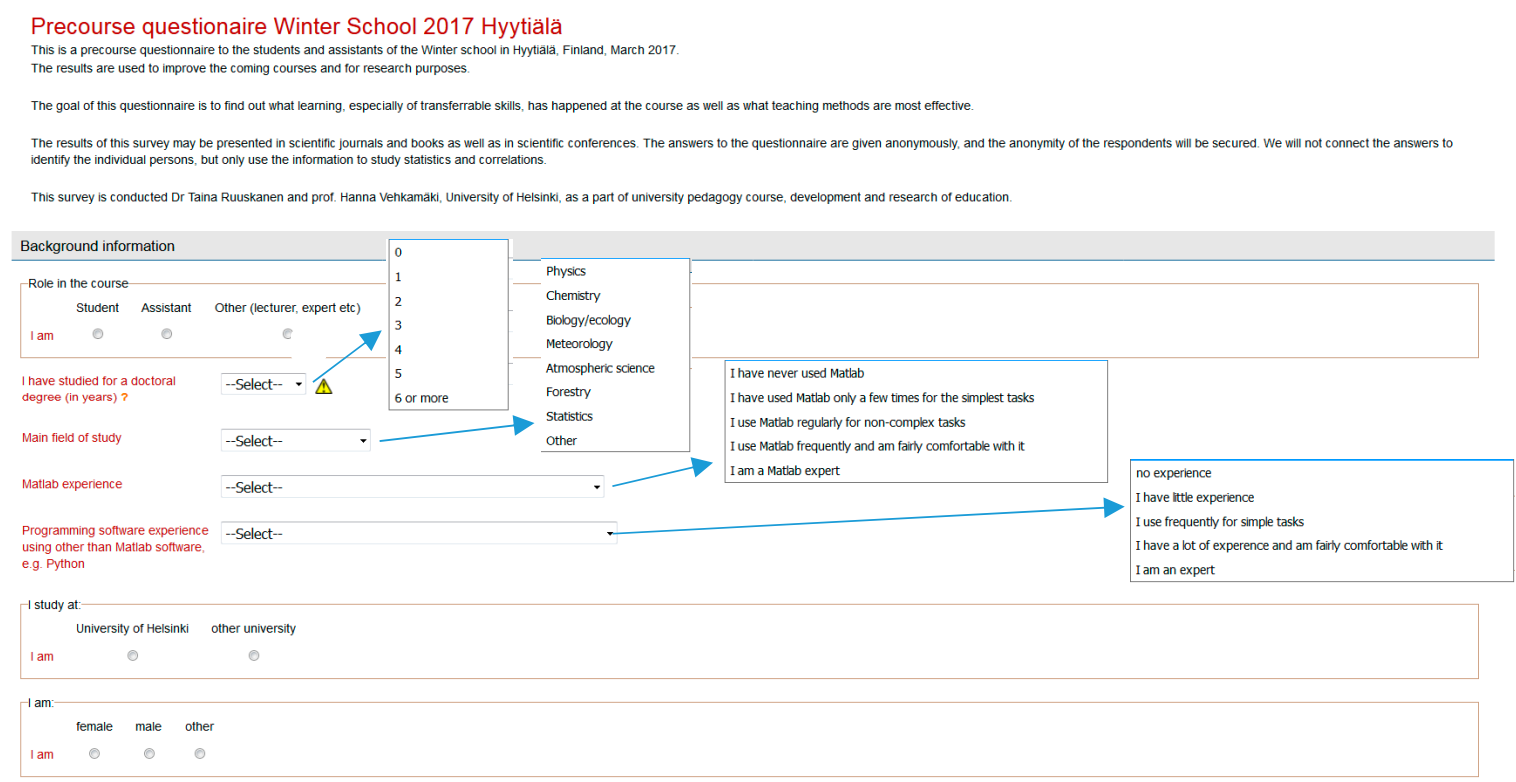




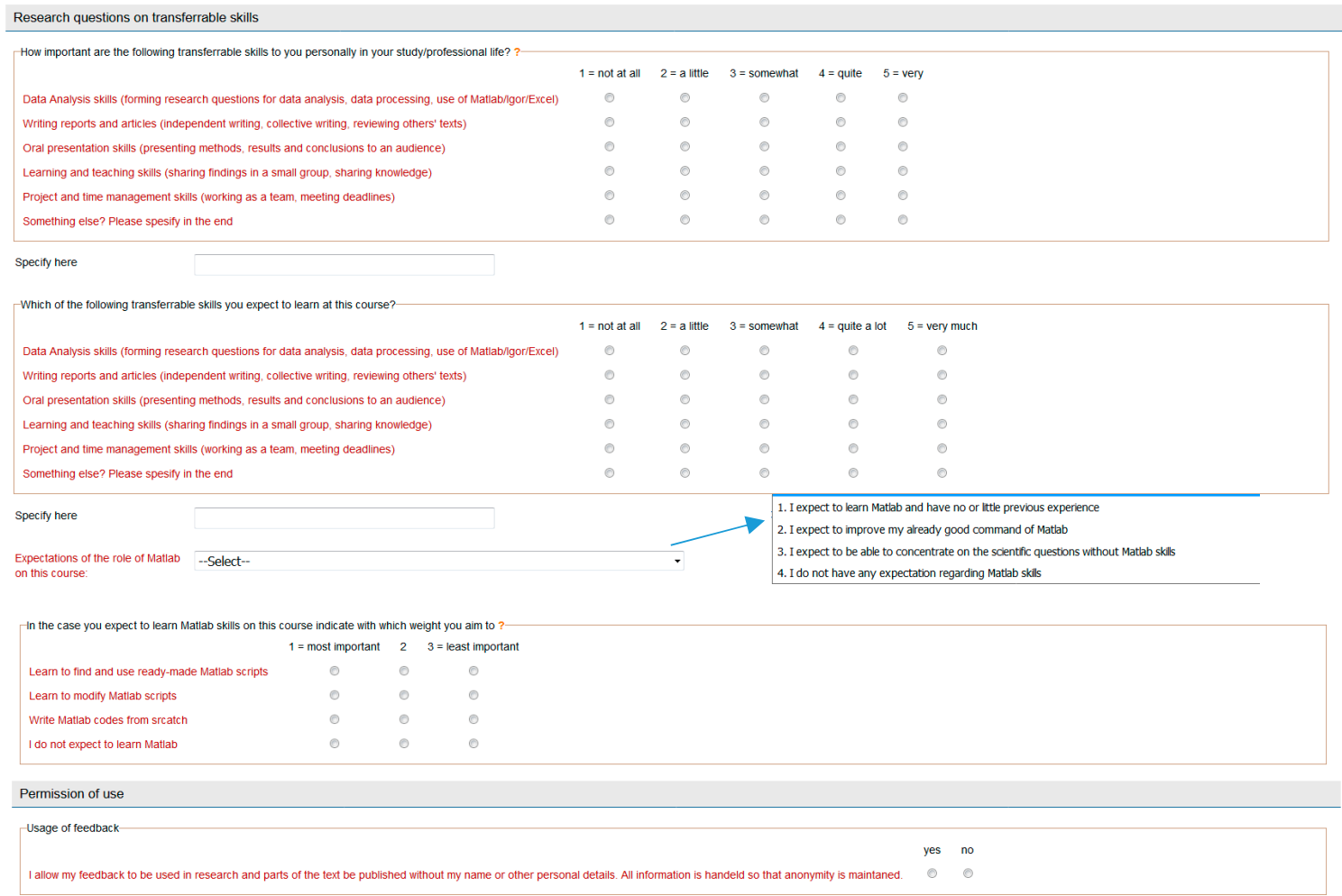

After course questionaire Winter School 2017 Hyytiälä

This is an after course questionnaire to the students and assistants of the Winter school in Hyytialä. Finland. March 2017.

The goal of this questionnaire is to find out what learning. especially of transterrable skills, has happened at the course as well as what teaching methods are most effective.

The results of this survey may be presented in scientific journals and books as well as in scientific conferences. The answers to the questionnaire are gven anonymously, and the anonymity of the respondents vill be secureed. We will not connect the answers to

This survey is conducted Dr Taina Ruuskanen and pror Hanna venkamakk, University or Hesisinki. as a part of university pedagogy course, development and research or education

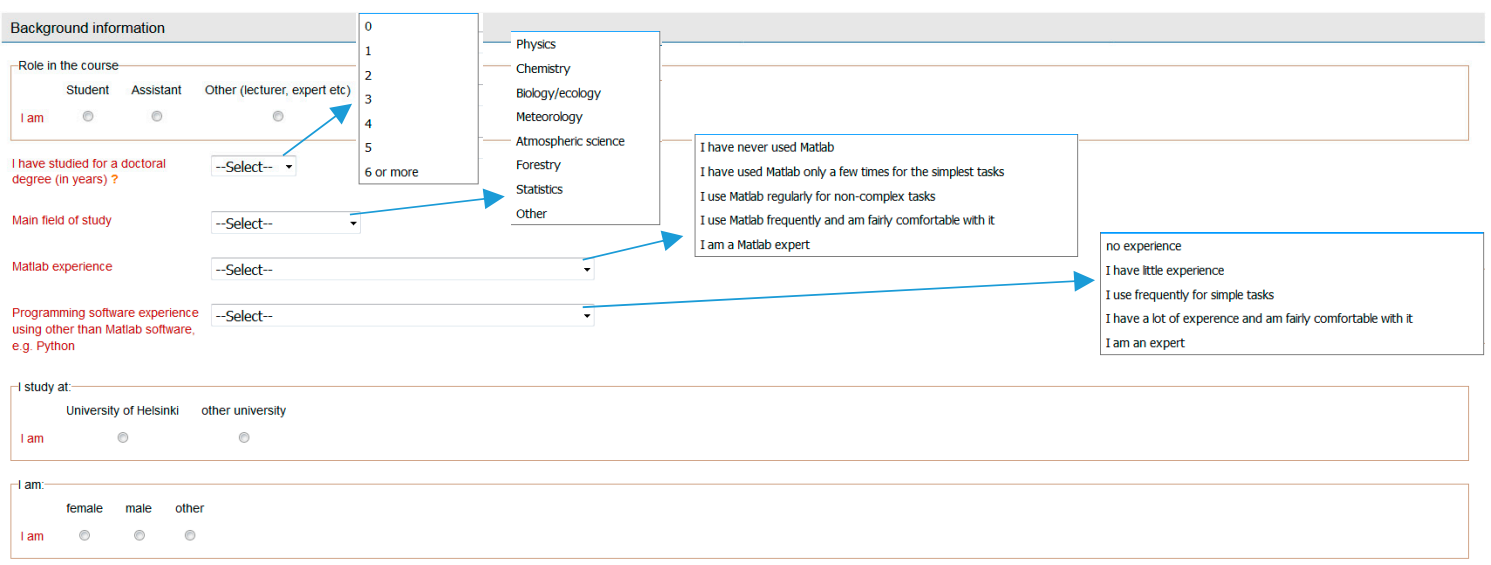




\begin{tabular}{|c|c|c|c|c|c|}
\hline Research questions on transferrable skills & & & & & \\
\hline 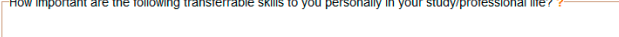 & $0=$ not used at all & $1=\mathrm{alitte}$ & $2=$ someunat & $3=$ quile a lot & $4=$ used very much \\
\hline Data Anaysis skills (torming research questions tor data analysis, data processing, use or Matabngorlexcel) & (-) & o & o & 0 & 0 \\
\hline Writting repors and ariclies (Independent writting, collective writting, reviemng others' terts) & (-) & ( & ( & 0 & ○ \\
\hline Oral presentation skills (presenting methods. results and conclusions to an audience) & 0 & 0 & 0 & 0 & 0 \\
\hline Learning and teaching skills (sharing findings in a smal group. sharing knowledge) & ○ & o & o & 0 & 0 \\
\hline Project and time management skills (working as a team, meeting deadlines) & 0 & o & o & 0 & o \\
\hline Something else? Please specify at the end & 0 & 0 & 0 & (-) & 0 \\
\hline
\end{tabular}

Specity here

\begin{tabular}{|c|c|c|c|c|c|}
\hline & $0=$ not at all & $1=\mathrm{a}$ little & $2=$ somewhat & $3=$ quite $a$ lot & $4=$ very much \\
\hline Data Anaysis skills (forming research questions for data analysis, data processing, use of MatablgorlExxel) & 0 & 0 & 0 & 0 & o \\
\hline Writing reports and articles (independent writing, collective writing, reviewing others' texts) & 0 & ○ & (0) & ( & 0 \\
\hline Oral presentation skills (presenting methods, results and conclusions to an audience) & 0 & ○ & ○ & ( & o \\
\hline Leaming and teaching skills (sharing fndings in a small group, sharing knowledge) & 0 & (-) & (0) & - & (0) \\
\hline Project and time management skills (working as atean, meeting deadines) & 0 & . & . & o & o \\
\hline Sometring else? Please spectiy at the end & 0 & (0) & (0) & - & (-) \\
\hline ment of the role of Matab - Select-n & & $\begin{array}{l}\text { 1. I learned M } \\
\text { 2. Improved } \\
\text { 3. I concentr }\end{array}$ & $\begin{array}{l}\text { lattab with no or lit } \\
\text { my aready good } \\
\text { ated on the scient }\end{array}$ & $\begin{array}{l}\text { te previous experic } \\
\text { command of Mata } \\
\text { fic questions witho }\end{array}$ & $\begin{array}{l}\text { ence } \\
\text { ab } \\
\text { ut Mattab sklls }\end{array}$ \\
\hline
\end{tabular}

Assesment of your Matlab (data-analysis) learning during the course ?

\begin{tabular}{|c|c|c|c|}
\hline & $3=$ most important & $1=$ least important & $0=1$ did not learn this \\
\hline Leamed to tind and use ready-made Matlab scripts & (D) & (-) & o \\
\hline Leamed to modiry Mallab scripts & 0 & 0 & - \\
\hline Learned to write Matlab codes from scratch & 0 & 0 & 0 \\
\hline
\end{tabular}

\begin{tabular}{|c|c|c|c|}
\hline \multirow{3}{*}{$\begin{array}{l}\text { Finding and getting data from AVAA -database was } \\
\text { Finding and getting data from the assistants/researchers }\end{array}$} & \multirow{3}{*}{$\begin{array}{c}1=\text { e easy } \\
0\end{array}$} & 23 & 45 5 difficut \\
\hline & & 00 & 0 \\
\hline & & 00 & 0 \\
\hline
\end{tabular}

\section{How would you improve AVAA
database?}

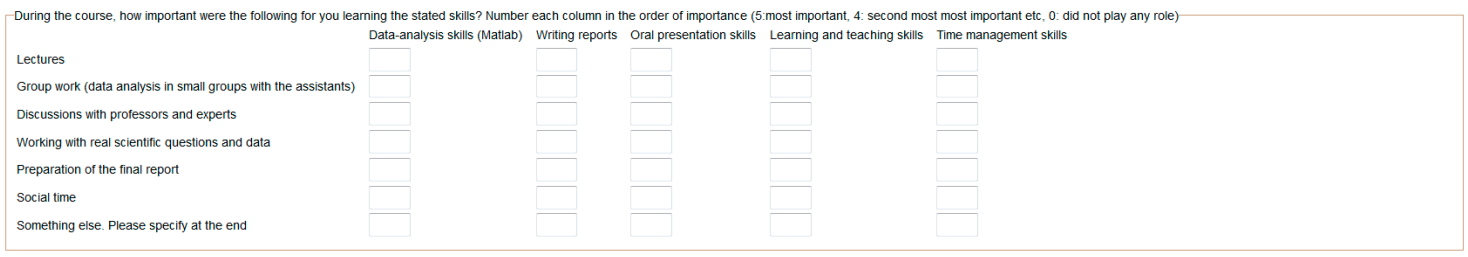

Specify here

What did you learn at the course?

\begin{tabular}{|c|c|c|c|}
\hline & I did not observe this & I observed this to some degree & This describes my role well \\
\hline You worked independently, while the group provided a support safety net & ๑ & o & ○ \\
\hline You took care of your own leaming, and both learned from and taught others & ( & . & ( \\
\hline You took a team leader role and managed practical things such as submissions and distribution of work & - & 0 & - \\
\hline Your hardly participated, and took acvantage of peers' answers & ( & o & () \\
\hline You tried, but found it persistently dificicut and you felt that you could not follow & - & o & ○ \\
\hline You tree (pernaps unconsclousiy) to hurry on to particular exercises, so that you could do the ones you preterred betore the others in the group got to them & ( & o & 0 \\
\hline Because of your previous knowledge, you recelved a dominant role in the group & 0 & 0 & - \\
\hline
\end{tabular}

Comments on the group work
and/or your own role at the course

\begin{tabular}{|c|c|c|c|c|c|}
\hline & $-2=$ tully disagree & -1 & 0 & 1 & z=tully agree \\
\hline The course was conceptually demanding & - & o & - & 0 & 0 \\
\hline The workload could have been higher & - & - & - & ( & - \\
\hline The formulation of the problem tor the group work was too droad & ๑) & o & 0 & B & D \\
\hline I enjoyed the course & 0 & 0 & 0 & D & D \\
\hline
\end{tabular}

Other feedback on the course 


\section{References}

1. Wiek, A.; Withycombe, L.; Redman, C.L. Key competencies in sustainability: A reference framework for academic program development. Sustain. Sci. 2011, 6, 203-218. [CrossRef]

2. Van der Leeuw, S.; Wiek, A.; Harlow, J.; Buizer, J. How much time do we have? Urgency and rhetoric in sustainability science. Sustain. Sci. 2012, 7, 115-120. [CrossRef]

3. Kulmala, M.K.; Lappalainen, H.; Petäjä, T.; Kerminen, V.-M.; Viisanen, Y.; Matvienko, G.; Melnikov, V.; Baklanov, A.; Bondur, V.; Kasimov, N.; et al. Pan-Eurasian EXperiment (PEEX) Program: Grand Challenges in the Arctic-Boreal Context. Geogr. Environ. Sustain. 2016, 9, 5-18. [CrossRef]

4. Mauser, W.; Klepper, G.; Rice, M.; Schmalzbauer, B.S.; Hackmann, H.; Leemans, R.; Moore, H. Transdisciplinary global change research: the co-creation of knowledge for sustainability. Curr. Opin. Environ. Sustain. 2013, 5, 420-431. [CrossRef]

5. Kemp, I.J.; Seagraves, L. Transferable skills—can higher education deliver? Stud. High. Educ. 1995, 20, 315-328. [CrossRef]

6. Bennett, R. Employers' demands for personal transferable skills in graduates: A content analysis of 1000 job advertisements and an associated empirical study. J. Vocat. Educ. Train. 2002, 54, 457-476. [CrossRef]

7. Nordic Climate Change Research. NordForsk Policy Briefs 2009-8; Mandag Morgen: Oslo, Norway, 2009.

8. Barrows, H.S. Problem-based learning in medicine and beyond: A brief overview. New Dir. Teach. Learn. 1996, 68, 3-12. [CrossRef]

9. Wood, D.F. ABC of learning and teaching in medicine: Problem based learning. BMJ 2003, $326,328$. [CrossRef] [PubMed]

10. Hall, P.; Weaver, L. Interdisciplinary education and teamwork: a long and winding road. Med. Educ. 2001, 35, 867-875. [CrossRef] [PubMed]

11. Reeves, S. Community-based interprofessional education for medical, nursing and dental students. Health Soc. Care Community 2000, 8, 269-276. [CrossRef] [PubMed]

12. Corter, J.E.; Esche, S.K.; Chassapis, C.; Ma, J.; Nickerson, J.V. Process and learning outcomes from remotely-operated, simulated, and hands-on student laboratories. Comput. Educ. 2011, 57, 2054-2067. [CrossRef]

13. Meehan, B.; Thomas, I. Teamwork: Education for entrants to the environment professions. Environ. Educ. Res. 2006, 12, 609-623. [CrossRef]

14. Spronken-Smith, R. Implementing a problem-based learning approach for teaching research methods in geography. J. Geogr. High. Educ. 2005, 29, 203-221. [CrossRef]

15. Mäkelä, J.M.; Aalto, P.; Jokinen, V.; Pohja, T.; Nissinen, A.; Palmroth, S.; Markkanen, T.; Seitsonen, K.; Lihavainen, H.; Kulmala, M. Observations of ultrafine aerosol particle formation and growth in boreal forest. Geophys. Res. Lett. 1997, 24, 1219-1222. [CrossRef]

16. Lauri, A.; Riuttanen, L.; Sihvonen, P.; Westerberg, S.; Hari, P.; Ruuskanen, T.M.; Kulmala, M. The atmospheric science paradigm and horizontal learning: experiences from short research-intensive courses. Rep. Ser. Aerosol Sci. 2016, 180, 275.

17. Biggs, J. Enhancing teaching through constructive alignment. High. Educ. 1996, 32, 347-504. [CrossRef]

18. Kolb, D.A. Experiental Learning: Experience as a Source of Learning and Development; Prentice-Hall: Engelwood Cliffs, NJ, USA, 1984.

19. Paramonov, M.; Lauri, A.; Sylvius, V.; Kulmala, M. Approaches for Multidisciplinary Research-Oriented Studies by Means of Joint Programmes: Cases, Experiences and Successes. Proceedings of Symposium on Integrating Research, Education, and Problem Solving (IREPS), Orlando, FL, USA, 2011; pp. 231-235.

20. Hari, P.; Kulmala, M. Stations for Measuring Ecosystem-Atmosphere Relations (SMEAR II). Boreal Environ. Res. 2005, 10, 315-322.

21. Junninen, H.; Lauri, A.; Keronen, P.; Aalto, P.; Hiltunen, V.; Hari, P.; Kulmala, M. Smart-SMEAR: on-line data exploration and visualization tool for SMEAR stations. Boreal Environ. Res. 2009, 14, 447-457.

22. Csikszentmihalyi, M. The Evolving Self: A Psychology for the Third Millennium; HarperCollins: New York, NY, USA, 1993; ISBN 0-06-016677-0.

23. Vygotsky, L. Interaction between Learning and Development. In Readings on the Development of Children; Gauvain, M., Cole, M., Eds.; Scientific American Books: New York, NY, USA, 1978; Volume 23, pp. $34-40$. 
24. Weber, B.; Hertel, G. Motivation Gains of Inferior Group Members: A Meta-Analytical Review. J. Pers. Soc. Psychol. 2007, 93, 973-993. [CrossRef] [PubMed]

25. Hennessy, S.; Murphy, P. The Potential for Collaborative Problem Solving in Design and Technology. Int. J. Technol. Des. Educ. 1999, 9, 1-36. [CrossRef]

26. Scott, P.A. Attributes of high-quality intensive courses. New Dir. Adult Contin. Educ. 2003, 97, 29-38. [CrossRef]

27. Kienzler, H.; Fontanesi, C. Learning through inquiry: A Global Health Hackathon. Teach. High. Educ. 2017, 22, 129-142. [CrossRef]

28. Leckart, S. The Hackathon Is On: Pitching and Programming the Next Killer App, WIRED. Available online: http:/ / www.wired.com/magazine/2012/02/ff_hackathons / (accessed on 20 November 2017).

29. Fincher, S.; Knox, D. The Porous Classroom: Professional Practices in the Computing Curriculum. Computer 2013, 46, 44-51. [CrossRef]

30. Pintrich, P.R. The Role of Metacognitive Knowledge in Learning, Teaching, and Assessing. Theory Pract. 2002, 41, 219-225. [CrossRef]

31. Isomöttönen, V.; Tirronen, V. Flipping and Blending-An Action Research Project on Improving a Functional Programming Course. ACM Trans. Comput. Educ. 2016, 17, 1-35. [CrossRef]

32. Seppänen-Järvelä, R. Prosessiarviointi Kehittämisprojektissa. Opas Käytäntöihin; Stakes, FinSoc Arviointiraportteja 4/2004; Stakes: Helsinki, Finland, 2004; ISBN 951-33-1742-0, ISSN 1458-1833.

33. Robson, C. Käytännön Arvioinnin Perusteet. Opas Evaluaation Tekijöille ja Tilaajille; Tammi: Helsinki, Finland, 2001.

34. Kirkpatric Model of Learning. Available online: http://www.kirkpatrickpartners.com/Home/tabid/38/ Default.aspx (accessed on 12 March 2018).

35. Sinche, M.; Layton, R.L.; Brandt, P.D.; O'Connell, A.B.; Hall, J.D.; Freeman, A.M.; Harrell, J.R.; Cook, J.G.; Brennwald, P.J. An evidence-based evaluation of transferrable skills and job satisfaction for science PhDs. PLoS ONE 2017, 12, e0185023. [CrossRef] [PubMed]

36. Walsh, E.; Seldon, P.M.; Hargreaves, C.E.; Alpay, E.; Morley, B.J. Evaluation of a programme of transferable skills development within the PhD: views of late stage students. Int. J. Res. Dev. 2010, 1, 223-247. [CrossRef]

37. Boud, D.; Lee, A. Peer learning' as pedagogic discourse for research education. Stud. High. Educ. 2005, 30, 501-516. [CrossRef]

38. Fenge, A.-L. Enhancing the doctoral journey: The role of group supervision in supporting collaborative learning and creativity. Stud. High. Educ. 2012, 37, 401-414. [CrossRef]

39. Malfroy, J. Doctoral supervision, workplace research and changing pedagogic practices. High. Educ. Res. Dev. 2005, 24, 165-178. [CrossRef]

40. Wisker, G.; Robinson, G.; Trafford, V.; Warnes, M.; Creighton, E. From Supervisory Dialogues to Successful PhDs: Strategies supporting and enabling the learning conversations of staff and students at postgraduate level. Teach. High. Educ. 2003, 8, 383-397. [CrossRef]

41. Caskey, S.R. Learning Outcomes in Intensive Courses. J. Contin. High. Educ. 1994, 42, 23-27. [CrossRef]

42. Li, X.; Huang, Z. An inverted classroom approach to educate MATLAB in chemical process control. Educ. Chem. Eng. 2017, 19, 1-12. [CrossRef]

43. Giabbanelli, P.J.; Mago, V.K. Teaching computational modeling in the data science era. Procedia Comput. Sci. 2016, 80, 1968-1977. [CrossRef]

44. Virtanen, V.; Taina, J.; Pyhältö, K. What disengages doctoral students in the biological and environmental sciences from their doctoral studies? Stud. Contin. Educ. 2017, 39, 71-86. [CrossRef]

(C) 2018 by the authors. Licensee MDPI, Basel, Switzerland. This article is an open access article distributed under the terms and conditions of the Creative Commons Attribution (CC BY) license (http://creativecommons.org/licenses/by/4.0/). 